\title{
STABILITY-INDICATING METHOD DEVELOPMENT AND VALIDATION FOR THE ESTIMATION OF ROSUVASTATIN CALCIUM IN BULK AND TABLET FORMULATION BY REVERSE-PHASE HIGH-PERFORMANCE LIQUID CHROMATOGRAPHY
}

\author{
SAILAJA B, SRAVANA KUMARI K* \\ Department of Pharmaceutical Analysis, Institute of Pharmaceutical Technology, Sri Padmavati Mahila Visvavidyalayam, Tirupati, \\ Andhra Pradesh, India. Email: sravanipharma117@gmail.com
}

Received: 24 April 2019, Revised and Accepted: 09 July 2019

\section{ABSTRACT}

Objective: The present work was focused on the development and validation of reverse-phase high-performance liquid chromatography (RP-HPLC) method which is simple, rapid, precise, accurate, sensitive, economical, and stability indicating for the quantitation of rosuvastatin calcium in bulk and tablet formulation.

Methods: The separation was attained on Waters Symmetry C18 column with dimensions $150 \times 4.6 \mathrm{~mm}, 5 \mathrm{~mm}$ particle size employing $0.1 \%$ orthophosphoric acid buffer:acetonitrile in the ratio of $55: 45 \% \mathrm{v} / \mathrm{v}$ as mobile phase, which was pumped at a rate of $1.0 \mathrm{ml} / \mathrm{min}$ and detected at a wavelength of $241 \mathrm{~nm}$.

Results: The linearity of the method was demonstrated in the concentration range of $2-12 \mu \mathrm{g} / \mathrm{ml}$ for rosuvastatin calcium with a correlation coefficient $\left(\mathrm{r}^{2}\right)$ of 0.999 . Percentage drug recovery was found to be $100.22-101.16 \%$, and percentage relative standard deviation was $<2 \%$. Limit of detection and limit of quantitation values were found to be $0.013 \mu \mathrm{g} / \mathrm{ml}$ and $0.042 \mu \mathrm{g} / \mathrm{ml}$, respectively, and assay of marketed tablet formulation was found to be $99.76 \%$.

Conclusion: The developed RP-HPLC method was found to be simple, specific, sensitive, rapid, linear, accurate, precise, and economical and could be used for regular quality control of rosuvastatin calcium in bulk and tablet formulation.

Keywords: Rosuvastatin calcium, Reverse-phase high-performance liquid chromatography, Validation, ICH guidelines.

(c) 2019 The Authors. Published by Innovare Academic Sciences Pvt Ltd. This is an open access article under the CC BY license (http://creativecommons. org/licenses/by/4. 0/) DOI: http://dx.doi.org/10.22159/ajpcr.2019.v12i8.33735

\section{INTRODUCTION}

Rosuvastatin calcium, an antihyperlipidemic agent which is 3-hydroxy-3-methylglutaryl coenzyme A (HMG CoA) reductase inhibitor used along with diet to lower plasma low-density lipoprotein (LDL) and triglyceride levels and to raise high-density lipoprotein (HDL) levels in hyperlipidemia patients. It reduces cardiovascular events and deaths in hyperlipidemia patients. It acts by competitively and reversibly inhibiting $\beta$-hydroxy- $\beta$-methylglutaryl-coenzyme A (HMG-CoA) reductase, thereby preventing the conversion of HMG-CoA to mevalonic acid, which is the rate-limiting step in cholesterol biosynthesis [1]. As diabetes increases the risk of cardiovascular diseases, it can be reduced by administering statins. Diabetic dyslipidemia is characterized by high levels of plasma triglycerides and LDL and low HDL levels. The main target in diabetic patients is to reduce LDL plasma levels to $<70 \mathrm{mg} / \mathrm{dl}$, which can be achieved using potent statins at adequate doses [2]. Chemically, it is a calcium salt of bis[(E)-7-[4(4-fluorophenyl)-6-isopropyl2-[methyl(methylsulfonyl)a mino]pyrimidin-5-yl] (3R,5S)-3,5dihydroxyhept-6-enoicacid]. The structure of rosuvastatin calcium is shown in Fig. 1. The drug is white to off-white powder, soluble in dimethylformamide, dimethyl sulfoxide, acetone, acetonitrile, slightly soluble in water, and methanol [3]. An extensive literature survey revealed that several HPLC methods were reported for the estimation of rosuvastatin calcium in bulk and formulation [4-18]. The reported methods have the drawbacks of long runtime and less economical with high proportions of organic phase. Hence, an attempt was made to develop reverse-phase high-performance liquid chromatography (RP-HPLC) method which is simple, rapid, accurate, precise, specific, economical, sensitive, and stability indicating for the estimation of rosuvastatin calcium in bulk and pharmaceutical tablet formulation.

\section{METHODS}

\section{Chemicals}

Reference standard of rosuvastatin calcium was obtained as gift sample from Apotex Pharma, Bengaluru. Rosuvastatin calcium, available as tablets under the trade name Rozavel 10 (Sun Pharma) with a label claim of $10 \mathrm{mg}$, was procured from the local pharmacy. Orthophosphoric acid, HPLC-grade water, acetonitrile, and methanol were procured from Merck Chemicals Limited.

\section{Chromatographic conditions}

Waters HPLC system with autosampler and PDA detector with Empower-2 software was used. The separation was achieved on Waters Symmetry C18 column $150 \times 4.6 \mathrm{~mm}, 5 \mathrm{~mm}$ particle size using $0.1 \%$ orthophosphoric acid buffer:acetonitrile in the ratio of $55: 45 \% \mathrm{v} / \mathrm{v}$ as mobile phase at a flow rate of $1.0 \mathrm{ml} / \mathrm{min}$, detection wavelength of $241 \mathrm{~nm}$, and column temperature of $30^{\circ} \mathrm{C}$. Injection volume was $10 \mu \mathrm{l}$. The optimized chromatographic conditions are shown in Table 1.

The diluent used was acetonitrile and water in the ratio of 1:1.

\section{Preparation of standard stock solution}

Accurately $10 \mathrm{mg}$ of rosuvastatin calcium standard was transferred to $10 \mathrm{ml}$ volumetric flask, $5 \mathrm{ml}$ of diluent was added to dissolve the drug and made up to the mark with diluent, filtered through $0.45 \mu \mathrm{m} \mathrm{HV}$ Millipore membrane filter to prepare $1000 \mu \mathrm{g} / \mathrm{ml}$ (standard stock-1). Standard stock solution- 2 was prepared by diluting $1 \mathrm{ml}$ of standard stock-1 to $10 \mathrm{ml}$ using diluent $(100 \mu \mathrm{g} / \mathrm{ml})$.

\section{Preparation of the sample stock solution}

Twenty tablets were weighed and calculated the average weight of tablet. The tablets were finely powdered and tablet powder equivalent 
to $10 \mathrm{mg}$ rosuvastatin calcium was weighed accurately and transferred to $10 \mathrm{ml}$ volumetric flask. About $5 \mathrm{ml}$ of diluent was added, sonicated, degassed, and made up to the mark with diluent, filtered through $0.45 \mu \mathrm{m}$ Millipore membrane filter (sample stock-1). Sample stock solution-2 was prepared by diluting suitable volume of sample stock-1 to $10 \mathrm{ml}$ using diluent $(100 \mu \mathrm{g} / \mathrm{ml})$.

\section{Preparation of standard and sample working solution}

About $10 \mu \mathrm{g} / \mathrm{ml}$ of standard and sample working solutions were prepared from the stock solution-II using diluent and were injected into the chromatographic system and chromatograms were recorded.

\section{Method validation}

The developed method was validated in accordance with ICH guidelines (ICH Q2R1) for accuracy, precision, specificity, linearity, limit of detection (LOD), limit of quantitation (LOQ), and robustness [19]

Accuracy

Accuracy of the developed method was established by standard addition method. The results were expressed in terms of percentage recovery. It was computed at three different levels $80 \%, 100 \%$, and $120 \%$ of the target sample concentration. The standard solution was spiked with predetermined sample concentration for preparing three concentration levels. Three injections of each level were injected and individual percentage recovery and mean percentage recovery values were calculated.

\section{Precision}

Precision of the developed method was established by performing intraday precision and interday precision. It was demonstrated by injecting $8 \mu \mathrm{g} / \mathrm{ml}$ concentration of sample solution at 6 different times

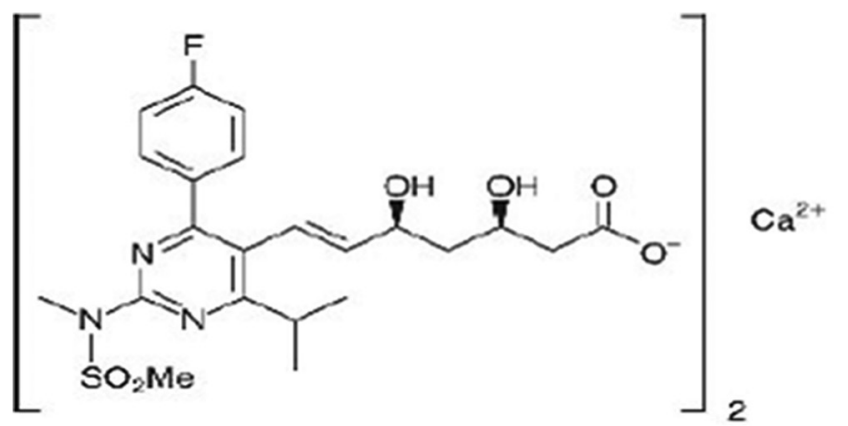

Fig. 1: Rosuvastatin calcium on the same day and 6 different days. The results of precision were expressed in terms of percentage relative standard deviation (\%RSD).

\section{Linearity}

Linearity of the developed method was entrenched at a concentration range of $2-12 \mu \mathrm{g} / \mathrm{ml}$. A series of solutions whose concentrations ranging from 2 to $12 \mu \mathrm{g} / \mathrm{ml}$ were prepared from the standard stock solution and three injections of each level were injected into the chromatographic system using $10 \mu \mathrm{l}$ fixed loop system and chromatograms were recorded. Calibration curve of peak area versus concentration was plotted and the correlation coefficient was calculated.

\section{Specificity}

Specificity of the developed method was established by comparing the chromatograms of blank, placebo, standard, and sample. It was found that there was no interference due to excipients and impurities at the retention time of the drug. The chromatogram is shown in Fig. 2.

\section{LOD and LOQ}

LOD and LOQ values were calculated using the formulae based on the standard deviation of the response and slope of the calibration curve. $\mathrm{LOD}=3.3 \sigma / \mathrm{S}$ and LOQ $=10 \sigma / \mathrm{S}$. Where, $\sigma$ is the standard deviation of Y-intercept of regression lines and $S$ is the slope of calibration curve. The LOD and LOQ for rosuvastatin calcium were found to be $0.013 \mu \mathrm{g} / \mathrm{ml}$ and $0.042 \mu \mathrm{g} / \mathrm{ml}$, respectively.

\section{Robustness}

Robustness was demonstrated by making small intended changes in the optimized chromatographic conditions. Parameters such as flow rate $( \pm 0.1 \mathrm{ml} / \mathrm{min})$, organic composition $( \pm 5 \mathrm{ml})$, and temperature $\left( \pm 5^{\circ} \mathrm{C}\right)$ were changed. Six replicate injections of each condition were injected and $\%$ RSD of peak area was calculated.

\section{Stability of the solution}

Stability of both the standard and sample solutions was checked up to $24 \mathrm{~h}$ at room temperature.

\section{Stability-indicating assay}

The drug was subjected to acidic $(0.1 \mathrm{~N} \mathrm{HCl})$, alkaline $(0.1 \mathrm{~N} \mathrm{NaOH})$, oxidative $\left(0.3 \% \mathrm{H}_{2} \mathrm{O}_{2}\right)$, photo (UV light), thermal (sand bath at $50^{\circ} \mathrm{C}$ ), and hydrolytic (water) conditions and the percentage degradation was calculated.

\section{RESULTS AND DISCUSSION}

RP-HPLC method was developed for the estimation of rosuvastatin calcium in bulk and tablet formulation. The method was modified by

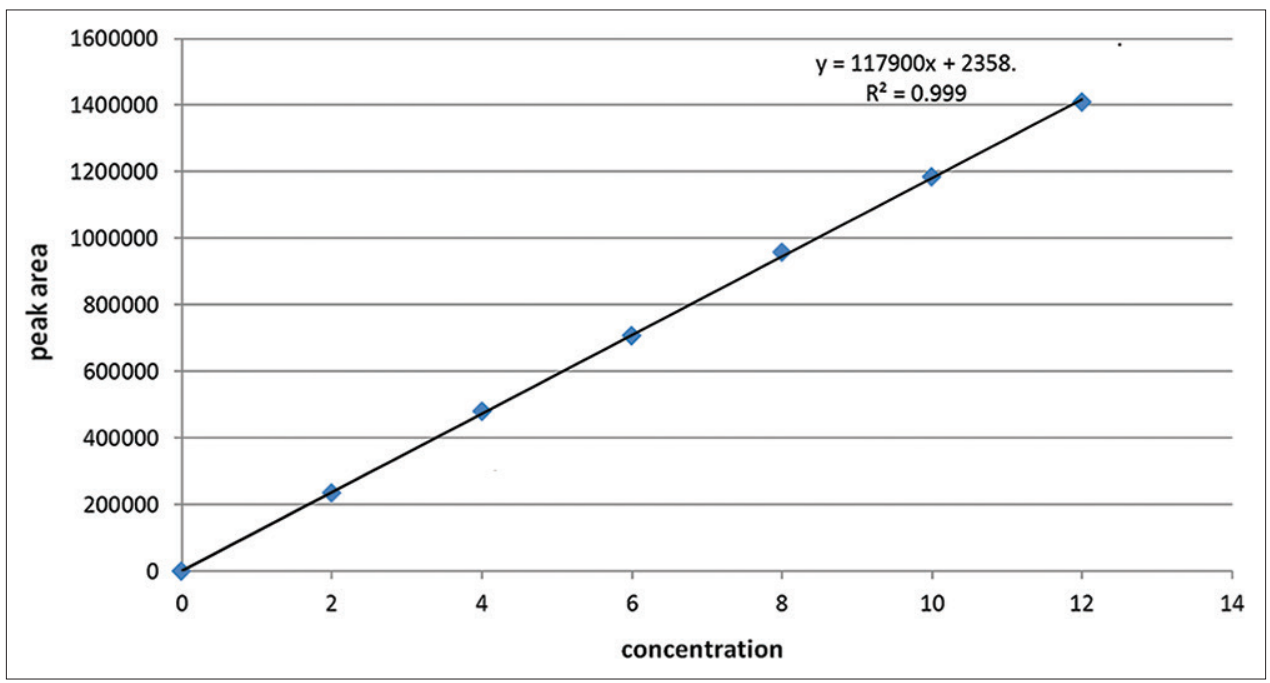

Fig. 2: Linearity plot 


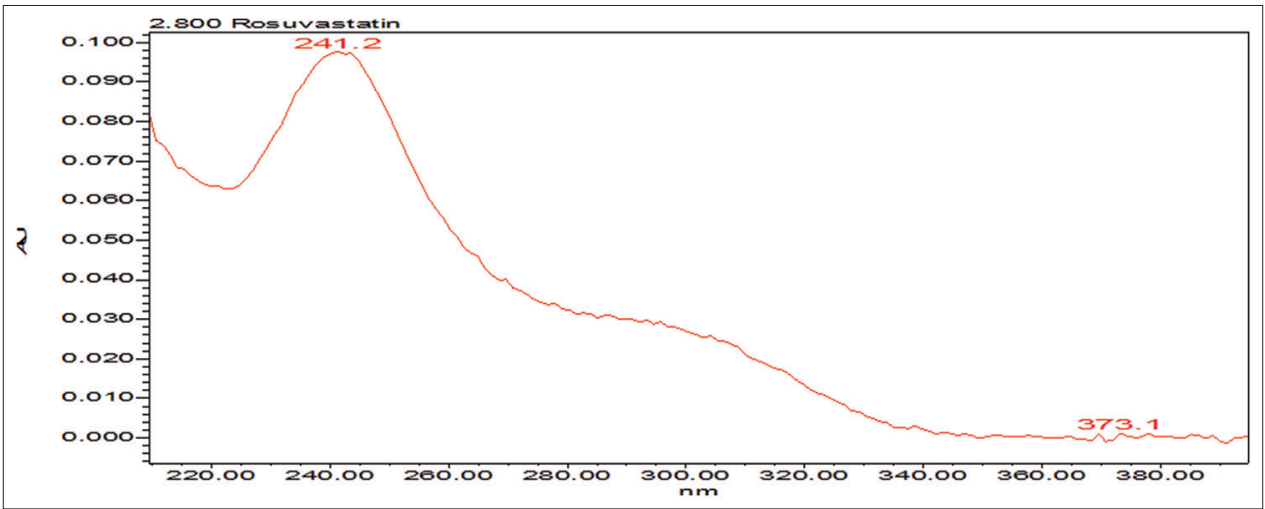

Fig. 3: UV spectrum of rosuvastatin calcium

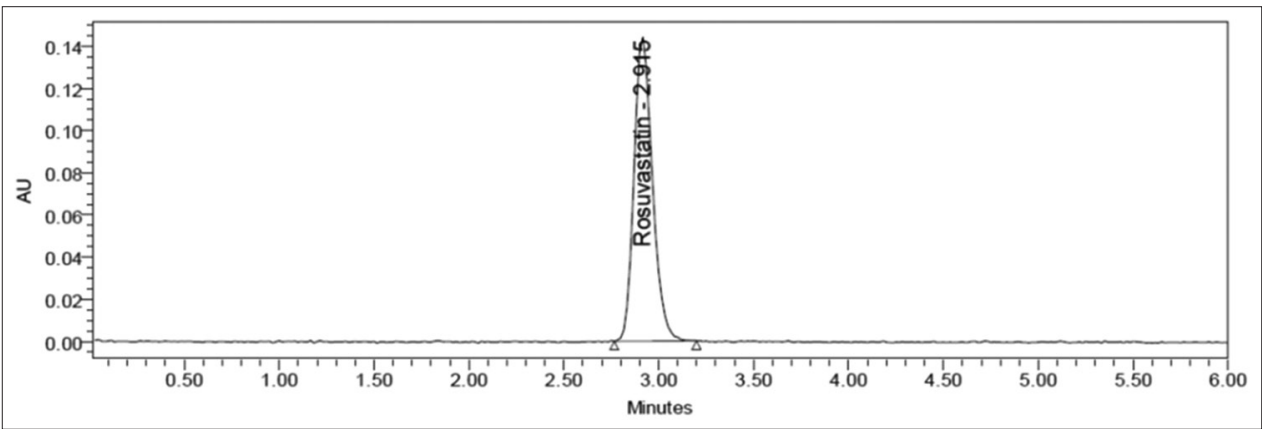

Fig. 4: Chromatogram of standard

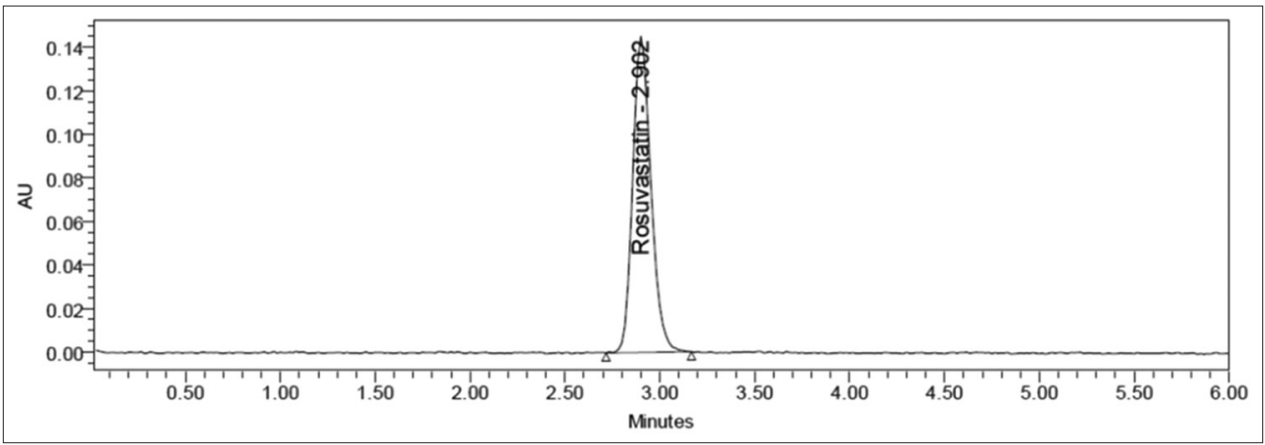

Fig. 5: Chromatogram of sample

Table 1: Optimized chromatographic conditions

\begin{tabular}{ll}
\hline \multicolumn{2}{l}{ Chromatographic conditions } \\
\hline Mobile phase & $0.1 \%$ OPA buffer:ACN \\
& $(55: 45)(\mathrm{pH}: 2.7)$ \\
Flow rate & $1.0 \mathrm{ml} / \mathrm{min}$ \\
Column & Waters C18 150×4.6 mm, $5 \mathrm{~mm}$ \\
Detector wavelength & $241.0 \mathrm{~nm}$ \\
Column temperature & $30^{\circ} \mathrm{C}$ \\
Injection volume & $10 \mathrm{~mL}$ \\
Runtime & $6 \mathrm{~min}$ \\
Retention time & $2.916 \mathrm{~min}$ \\
Diluent & Acetonitrile:water (50:50) \\
\hline
\end{tabular}

varying columns, mobile phase, and flow rate and using columns of various lengths to obtain the simple and efficacious method. Detection wavelength was selected by scanning the standard concentration in the wavelength range of $200-400 \mathrm{~nm}$, and $\lambda \max$ was found to be $241 \mathrm{~nm}$ (UV spectrum is shown in Fig. 3).
Diluent was selected on the basis of solubility of the drug. As rosuvastatin calcium was slightly soluble in water, acetonitrile and water in the ratio of 1:1 was used as diluent. The method was developed employing Waters Symmetry C18 column $150 \times 4.6 \mathrm{~mm}, 5 \mathrm{~mm}$ particle size with $0.1 \%$ orthophosphoric acid buffer and acetonitrile in the ratio of $55: 45 \% \mathrm{v} / \mathrm{v}$ as mobile phase at a column temperature of $30^{\circ} \mathrm{C}$. Mobile phase was forced at a flow rate of $1.0 \mathrm{ml} / \mathrm{min}$. The drug rosuvastatin calcium was detected at a wavelength of $241 \mathrm{~nm}$. About $10 \mu \mathrm{l}$ solution was injected into the chromatographic system. The total runtime was 6 min with a retention time of $2.915 \pm 0.1 \mathrm{~min}$. The chromatograms of the standard and sample are shown in Figs. 4 and 5.

Suitability of the system was demonstrated by assessing various parameters. It was established by injecting six replicate injections of the standard solution. Theoretical plates were found to be 4537, tailing factor of 1.20 , and \%RSD of peak area was 0.4 (Table 2). All the system suitability parameters were well within the limits, indicating that the system was well suitable for performing the analysis.

The developed method was validated. Accuracy was computed by recovery studies. The mean percentage recovery values for three levels 


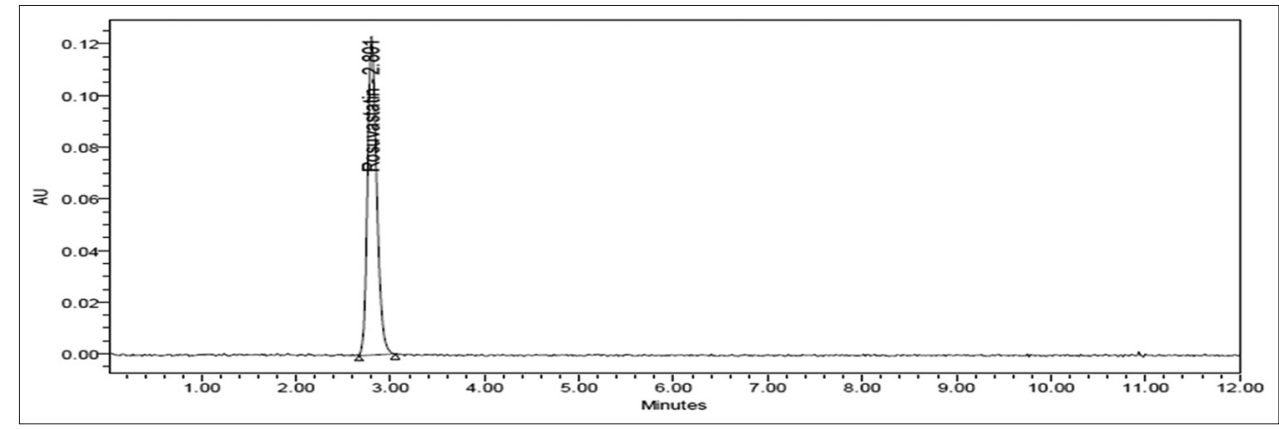

Fig. 6: Acidic degradation of rosuvastatin calcium

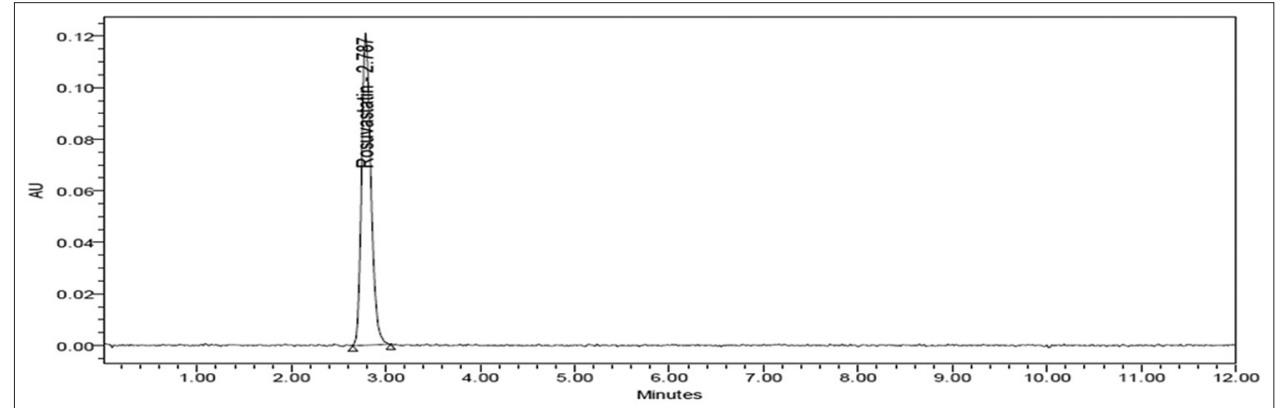

Fig. 7: Alkaline degradation of rosuvastatin calcium

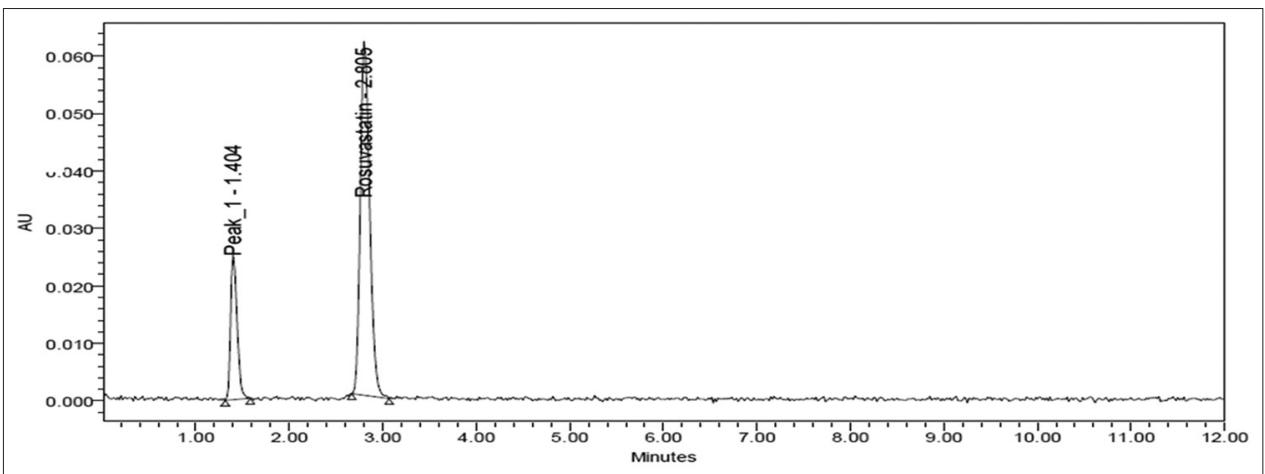

Fig. 8: Oxidative degradation of rosuvastatin calcium

Table 2: System suitability data

\begin{tabular}{ll}
\hline Parameter & Result \\
\hline Theoretical plates & 4537 \\
Tailing factor & 1.19 \\
\%RSD & 0.4 \\
\hline
\end{tabular}

\%RSD: Percentage relative standard deviation

Table 3: Accuracy data

\begin{tabular}{lllll}
\hline $\begin{array}{l}\text { Sample conc. } \\
(\boldsymbol{\mu g} / \mathbf{m l})\end{array}$ & Level (\%) & $\begin{array}{l}\text { Amount } \\
\text { added } \\
(\boldsymbol{\mu g} / \mathbf{m l})\end{array}$ & $\begin{array}{l}\text { Amount } \\
\text { found* } \\
(\boldsymbol{\mu g} / \mathbf{m l})\end{array}$ & \% recovery* \\
\hline 8 & 80 & 6.4 & 14.43 & 100.22 \\
8 & 100 & 8 & 16.18 & 101.16 \\
8 & 120 & 9.6 & 17.74 & 100.81 \\
\hline
\end{tabular}

*Average of three determinations

were found to be between $100.22 \%$ and $101.16 \%$. The percentage recovery values were within the limits, indicating that the method developed was accurate (Table 3).
Results of intraday precision and interday precision were 0.8 and 0.3 $(<2.0)$, indicate that the method was precise. Calibration curve of peak area versus concentration for rosuvastatin calcium was constructed (Fig. 2). The linear regression equation obtained was $y=117900 x+2358$ and a correlation coefficient of 0.999 , indicating the good linear relationship between the concentration and peak area. The method was found to be linear in the concentration range of $2-12 \mu \mathrm{g} / \mathrm{ml}$.

The calculated LOD and LOQ values for the method were $0.013 \mu \mathrm{g} / \mathrm{ml}$ and $0.042 \mu \mathrm{g} / \mathrm{ml}$. Values of LOD and LOQ $<0.1 \mu \mathrm{g} / \mathrm{ml}$ indicate that the method was greatly sensitive Table 6 .

The chromatograms of placebo and blank suggest that no interference was observed due to excipients and impurities. Hence, the developed chromatographic method was found to be highly specific. The chromatograms of the standard and sample reflect that sample peak was obtained at the same retention time of the standard peak, thereby confirming the drug present in tablet formulation was rosuvastatin calcium. Robustness of the method was designed by changing the optimized conditions adequately. On assessment of the results (Table 4), it can be deduced that the variation in the composition of mobile phase, flow rate, and temperature does not affect the method significantly. $\%$ RSD of $<2 \%$ specifies that the developed method was robust. 


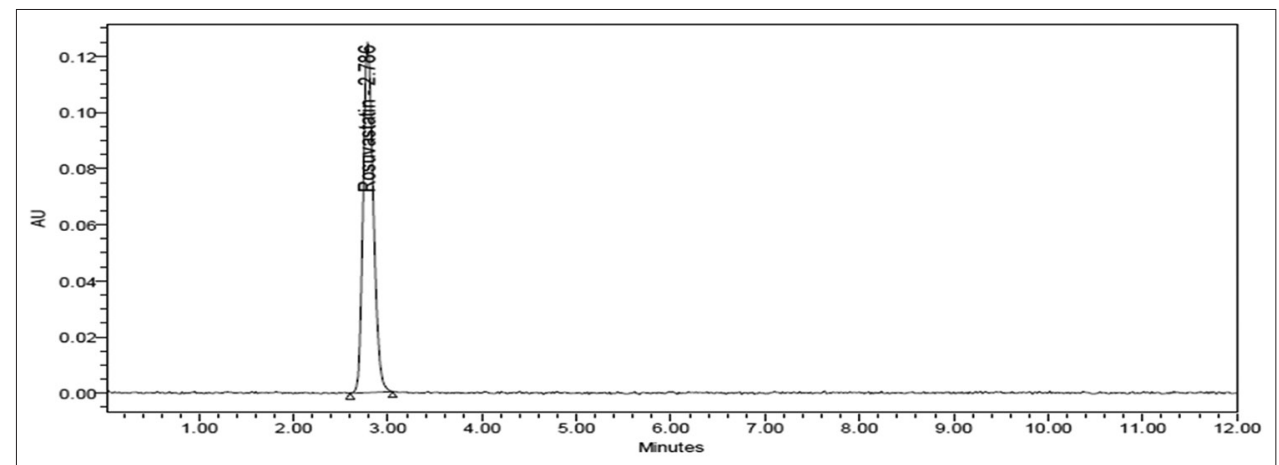

Fig. 9: Photodegradation of rosuvastatin calcium

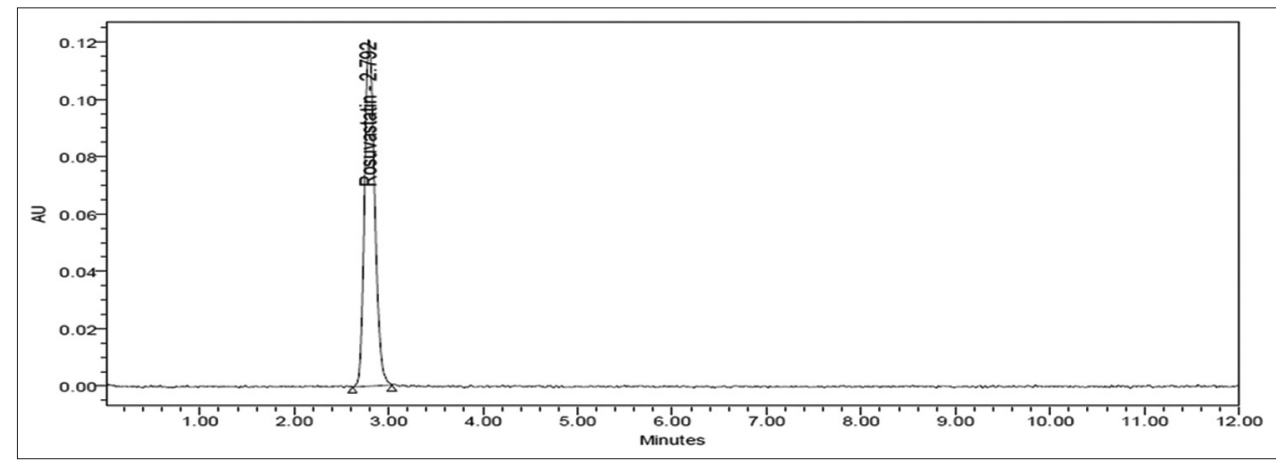

Fig. 10: Thermal degradation of rosuvastatin calcium

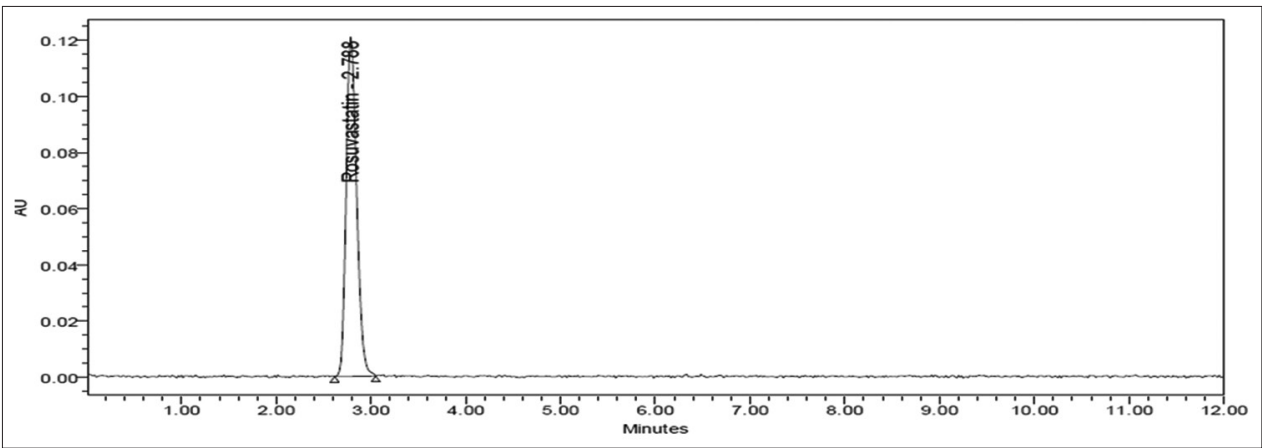

Fig. 11: Hydrolytic degradation of rosuvastatin calcium

Table 4: Robustness data

\begin{tabular}{|c|c|c|c|c|}
\hline Parameter & Optimized condition & Variation & $\%$ RSD & Retention time (min)* \\
\hline \multirow[t]{2}{*}{ 1. Flow rate $( \pm 0.1 \mathrm{ml} / \mathrm{min})$. } & $1 \mathrm{ml} / \mathrm{min}$ & 0.9 & 1.0 & 3.11 \\
\hline & & 1.1 & 0.5 & 2.54 \\
\hline \multirow{2}{*}{ 2. Mobile phase $( \pm 5 \mathrm{ml}$ ) (buffer: $\mathrm{ACN})$} & $55: 45$ & $50: 50$ & 0.8 & 2.35 \\
\hline & & $60: 40$ & 0.4 & 3.55 \\
\hline \multirow{2}{*}{ 3. Temperature $\left( \pm 5^{\circ} \mathrm{C}\right)$} & $30^{\circ} \mathrm{C}$ & 25 & 0.6 & 3.19 \\
\hline & & 35 & 0.5 & 2.50 \\
\hline
\end{tabular}

*Average of three determinations

Percentage assay of tablet formulation was found to be $99.76 \%$. The stability of the drug solutions was observed for $24 \mathrm{~h}$. \%RSD of 0.8 indicates the stability of the method for $24 \mathrm{~h}$. In degradation studies, drug was exposed to various stress conditions. From the chromatograms of stressed samples, it was found that no interference from degradants was observed at the retention time of rosuvastatin calcium. Optimum degradation was observed in the presence of acid and alkali. Substantial degradation was observed in the presence of peroxide and heat. Negligible degradation was observed in the presence of water and light. The results are presented in Table 5 and Figures 6-11. Hence, the method was found to be specific.

\section{CONCLUSION}

The developed stability-indicating RP-HPLC method was found to be rapid, simple, specific, sensitive, linear, accurate, precise, and economical for the estimation of rosuvastatin calcium in bulk and formulation. Hence, it could be used for the routine quality control of rosuvastatin calcium in bulk and formulation. 
Table 5: Stability-indicating method data of rosuvastatin calcium

\begin{tabular}{lll}
\hline S. No. & Stress condition & \% degradation \\
\hline 1 & Acidic $(0.1 \mathrm{~N} \mathrm{HCl} \mathrm{for} 24 \mathrm{~h})$ & 9.27 \\
2 & Alkaline $(0.1 \mathrm{~N} \mathrm{NaOH} \mathrm{for} 24 \mathrm{~h})$ & 8.44 \\
3 & Oxidative $\left(0.3 \% \mathrm{H}_{2} \mathrm{O}_{2}\right.$ for $\left.24 \mathrm{~h}\right)$ & 6.19 \\
4 & Photo $\left(\mathrm{UV}\right.$ light 200 watt-hours $/ \mathrm{m}^{2}$ for $\left.6 \mathrm{~h}\right)$ & 1.85 \\
5 & Thermal (sand bath at $50^{\circ} \mathrm{C}$ for $\left.6 \mathrm{~h}\right)$ & 2.32 \\
6 & Hydrolytic (HPLC water for $24 \mathrm{~h})$ & 0.59 \\
\hline
\end{tabular}

HPLC: High-performance liquid chromatography

Table 6: Summary of validation parameters

\begin{tabular}{ll}
\hline Parameters & Rosuvastatin calcium \\
\hline Calibration range $(\mu \mathrm{g} / \mathrm{ml})$ & $2-12$ \\
Optimized wavelength & $241 \mathrm{~nm}$ \\
Retention time & $2.915 \mathrm{~min}$ \\
Regression equation $(\mathrm{Y})$ & $\mathrm{y}=117900 \mathrm{x}+2358$ \\
Slope & 117900 \\
Intercept & 2358 \\
Correlation coefficient $\left(\mathrm{r}^{2}\right)$ & 0.999 \\
Precision $(\% \mathrm{RSD})$ & Intraday -0.8 \\
& Interday -0.3 \\
$\%$ Assay* & 99.76 \\
$\mathrm{LOD}(\mu \mathrm{g} / \mathrm{ml})$ & 0.013 \\
$\mathrm{LOQ}(\mu \mathrm{g} / \mathrm{ml})$ & 0.042 \\
\hline
\end{tabular}

*Average of five determinations. LOD: Limit of detection, LOQ: Limit of quantitation

\section{ACKNOWLEDGMENTS}

The authors are grateful to Apotex Pharma, Bengaluru, for providing the gift sample of rosuvastatin calcium to carry out the above research work.

\section{AUTHORS' CONTRIBUTIONS}

SB and SK designed the study. SK performed the experiment and analyzed the data and reviewed. SB supervised the experiment, reviewed the data, and supported for writing the manuscript.

\section{CONFLICTS OF INTEREST}

Authors declare that they have no conflicts of interest exist in this investigation.

\section{REFERENCES}

1. Luvai A, Mbagaya W, Hall AS, Barth JH. Rosuvastatin: A review of the pharmacology and clinical effectiveness in cardiovascular disease. Clin Med Insights Cardiol 2012;6:17-33.
2. Barrios V, Escobar C. Rosuvastatin and diabetes: When the evidences talk. Cardiovasc Hematol Agents Med Chem 2013;11:115-24.

3. Sweetman SC. Martindale: The Complete Drug Reference. London, England, UK: Pharmaceutical Press; 2002.

4. Hassouna ME, Salem HO. Stability indicating new RP-HPLC method for the determination of rosuvastatin calcium in pure and tablets dosage forms. Int J Appl Pharm Biol Res 2017;2:11-27.

5. SirishaMulukuri NV, Srinivasarao T, Raveendra BG. New RP-HPLC method development and validation for the estimation of rosuvastatin calcium in bulk drugs and formulations. J Pharm Res 2017;11:257-60.

6. Suares D, Prabhakar B. Stability-indicating assay method for determination of rosuvastatin in nano-formulation and pharmaceutical dosage form by RP-HPLC. Int J Pharm Tech Res 2016;9:265-74.

7. Ustun Z, Tala A, Demiralay EC. Optimization of RPLC conditions for quantitative analysis of atorvastatin and rosuvastatin in pharmaceutical dosage form. SDU J Sci E J 2016;11:72-81.

8. Rao BK, Rao MN, Ramu G, Rambabu C. Validated stability indicating rp-hplc method development for the assay of rosuvastatin in pure and formulations. ACAIJ 2015;15:160-8.

9. Moodbidri PV, Dhayanithi V, Shastry GB, Pati HN, Vasireddy P. Development and validation of chiral HPLC method for quantitation of enantiomer in rosuvastatin calcium. Int J Pharm Drug Anal 2015;3:275-82.

10. Babu CR, Gowrisankar D, Suribabu C, Badaree K, Sarvaraidu C. Development and validation of a reverse-phase HPLC method for the determination of rosuvastatin in pharmaceutical dosage forms. Res J Pharm Biol Chem Sci 2013;4:1791-9.

11. Chakraborty AK, Mishra SR Sahoo H. Formulation of dosage form of rosuvastatin calcium and development of validated RP-HPLC method for its estimation. Int J Anal Bioanal Chem 2011;1:89-101.

12. Donthula S, Kumar MK, Teja GS, Kumar YM, Krishna JY, Ramesh D. A new validated RP-HPLC method for determination of rosuvastatin calcium in bulk and pharmaceutical dosage form. Der Pharm Lett 2011;3:350-6.

13. Pandya CB, Channabasavaraj KP, Chudasama JD, Mani TT. Development and validation of RP-HPLC method for determination of rosuvastatin calcium in bulk and pharmaceutical dosage form. Int $\mathrm{J}$ Pharm Sci Rev Res 2010;5:82-6.

14. Kaila HO, Ambasana MA, Thakkar RS, Saravaia HT, Shah AK. A new improved RP-HPLC method for assay of rosuvastatin calcium in tablets. Indian J Pharm Sci 2010;72:592-8.

15. Rao AL, Suneetha D. Development and validation of RP-HPLC method for the estimation of rosuvastatin in bulk and pharmaceutical dosage form. Int J Chem Sci 2010;8:1308-14.

16. Raj HA, Rajput SJ, Dave JB, Patel CN. Development and validation of two chromatographic stability-indicating methods for determination of rosuvastatin in pure form and pharmaceutical preparation. Int J Chem Tech Res 2009;1:677-89.

17. Sri DS, Kumar TH, Rao KV, Rao YS. Validated RP-HPLC method for simultaneous determination of rosuvastatin calcium and ezetimibe in pharmaceutical dosage form. Int J Pharm Pharm Sci 2015;7:209-13.

18. Moinuddin M, Rahaman SA, Yadav BR, Battu RK. Development and validation of reverse phase HPLC method for simultaneous estimation of rosuvastatin calcium and fenofibrate in tablet dosage form. Int $\mathrm{J}$ Pharm Pharm Sci 2012;4:150-4.

19. Available from: https://www.ich.org/fileadmin/Public Web Site/ICH Products/Guidelines/Quality/Q2_R1/Step4/Q2_R1_Guideline.pdf. 